\title{
Risk Management Practices in Islamic and Conventional Banks of Bangladesh: A Comparative Analysis
}

\author{
Muhammad Mahbubur Rahman ${ }^{1}$, Md. Azizur Rahman ${ }^{1} \&$ Md. Abul Kalam Azad ${ }^{1}$ \\ ${ }^{1}$ Department of Business Administration, International Islamic University Chittagong, Bangladesh \\ Correspondence: Muhammad Mahbubur Rahman, Department of Business Administration, International Islamic \\ University Chittagong, Bangladesh. E-mail: mahbub.dba.iiuc@gmail.com
}

\author{
Received: March 3, 2015 Accepted: March 23, 2015 Online Published: June 5, 2015 \\ doi:10.5539/ass.v11n18p153 URL: http://dx.doi.org/10.5539/ass.v11n18p153
}

\begin{abstract}
Risk management is said to be a cornerstone of prudent banking practices. Banking sector in today's complex economic system has been facing a number of potential risks. The major ones are liquidity risk, credit risk, interest rate risk, investment risk, operational risk, and strategic risk which may threaten a bank's survival and success. Banks are, therefore, required to follow some prescribed procedures for identification and assessment of risk. Risk management in banking sector of Bangladesh has already shown increasing efficiency in governing banks. In an era of Globalization and Liberalization when remarkable expansion in the banking sector is seen, risk is a vital issue to focus on. Two categories of banks are operating in Bangladesh - Islamic (i.e. profit and loss sharing based) and conventional (i.e. interest or predetermined claim based). This paper aims at examining the risk management practices in both types of the banks in Bangladesh. The study reveals that regarding awareness among the bank personnel, there is a significant variation between the Islamic and conventional banks. Again, with respect to risk identification and understanding, management practices in conventional banks seem better than the Islamic ones. The study also indicates that the conventional banks relay mostly on advanced techniques of risk management. This study contributes in identifying the ways to estimate the efficiency of Risk Management.
\end{abstract}

Keywords: risk management practices, Sharia'h compliance, capital adequacy, Islamic and conventional banks

\section{Introduction}

The banking industry has been facing a number of crises around the world in last few decades. Banks that had been doing well suddenly were shocked by large losses because of imbalanced credit exposures, unadjusted interest rate or derivative exposures that were not assumed to hedge by adjusting balance sheet risk. As a result, commercial banks have felt the necessity to upgrade the total risk management systems. Moreover, as there are two types of banking systems, Islamic and Conventional, exists in Bangladesh, both Islamic and Commercial banks are not facing the same type of risk from the same direction. This study, therefore, exposed the gap of the risk identification, measurement and management practices between these two dimensions banking systems. In today's world, banks are the breadwinners of major financial services. Besides offering the maximized value to the shareholders, banks concentrate on profit maximization. In doing so, they compromise a variety of financial products in a competitive manner. The association of risk with these financial products differ significantly due to diverse characteristics of these products. Hence, risk management in banking typically demands for special classifications of risk management techniques. According to Carey (2001), risk management is the foundation of banking business because it allows the banks to offer services sustainably and at a regular fashion. There are a number of sources of risks for banking business. These are including liquidity risk, default risk, interest rate risk, etc. Some authors rename the banking business as a business of risk. The better a bank can manage its risk, the greater its performance in the long run. This paper fills the gap in existing literature by distinguishing the existing risk management practices in Bangladesh.

The classification of risks in association with banking business is twofold; controllable risks and uncontrollable risks. Controllable risks are micro level risks. These are related to bank's specific characteristics (i.e., asset quality, loan quality, management practices, etc.). On the other hand, the risks which are associated with macro level factors such as market, government and natural force are known as uncontrollable or systemic risks. Oldfield and Santomero (1997) examined the controllable risks in banking business. According to their outputs, 
there are three generic risk mitigation techniques that banks can adopt to minimize risks. These are: 1) a strategic business practice can help to avoid risk without taking it, 2) banks can transfer risk from one to another; and 3) taking risk with compliance to management ability in managing so. Hence, risk management can be practiced in different forms among the banks. This study contributes in finding the difference in risk management practices between selected two categories of banking business.

\section{Statement of the Problem}

The necessity of advanced risk management practices has been originated from the background studies of several world financial crises in last few decades. Special attention gained from the financial crunch of 2008. Not only the developed countries have been affected through these crises but also the developing countries have been suffering a lot. International financial institutions and their regulators have been seeking a solution that helps the modern banking business to be risk adjustable and sustainable. In banking business, risk management practices are defined as the combination of three major aspects. These are: 1) bank managers can identify the major sources of risks and understand the severity of availing such risk, 2) ability to monitor the movement of riskiness of the banks and to forecast what may happen if all goes wrong and 3) finally, know how to mitigate the risk by avoiding or transferring through state of art techniques. Hence, in the present world economic condition it is a timely approach to define banking risk and find a solution for a sustainable future. Developed countries, however, added few regulations regarding capital adequacy. We are of the opinion that only an increase in capital would not be sufficient in handling the dynamic nature of banking risk. As a special area of focus, bank's risks need to be examined combining both the empirical and behavioural aspects of bank personnel related to their attitude in managing risk. As prescribed earlier, bank personnel may differ in their strategy of risk identification and risk mitigation techniques.

Risk identification, measurement and mitigation are three major aspects of risk management. In practice, there are dissimilarities between the conventional and Islamic banks. This is because of the fact that conventional banks run on interest based system but Islamic banks run on profit sharing system. As a result, the concept of risk in Islamic financial system as well as conventional financial system varies to a greater extent. From the point of view of an Islamic financial system, the state of risks arises from two classified sources. First, risk must not be associated with "Gharar" (Uncertainty). Gharar, in the eye of Shariah is any element asymmetric information. If any risk is associated with speculation without realistic information and no scope of economic development happens in a contract, this will be treated as "gharar". Second, the member parties in a contract must enjoy freedom of contract which means, there should have a scope of bargain in the contract. Conventional banking fully differs in these respects. Depositors in a conventional bank has predetermined claim on bank's total asset. Despite having loss in any financial year, conventional banks therefore must undergo with the contact and risk remains fully unconditional and uncertain. Comparing to the conventional banks, Islamic banks have a superior quality of risk sharing rather risk accumulation. The return on their investment by the bank remains unknown. In the context of Bangladesh, a limited work is found in the stated research area. Moreover, comparative study on risk management practices for developing economies like Bangladesh is not available to the best of our knowledge. Hence, it is the demand of time to investigate the risk management practices in the two main banking systems in Bangladesh.

\section{Literature Review}

Significant studies have examined risk management practices worldwide. However, the empirical studies in the context of Bangladesh are scarce. Moreover, the number of publications showing comparison between the conventional banking and Islamic banking seems to be scanty. The following is an endeavour to capture the core findings from major literature. Linbo (2004) worked with risk management in major banks of United States. The author provides two important information on the bank efficiency. His finding suggests that profitability is sensitive to credit risk. According to Ho Hahm (2004), interest rate risk is a common phenomenon in Korean commercial banks than the exchange rate risks. Niinima"ki (2004) mentioned that the degree of risk taking depends on the structure and side of the market in which competition takes place. If the banks work in a monopoly market or banks are competing only in the loan market, deposit insurance has no effect on risk taking. Banks in this situation tend to take more risk than that of a competitive market operator, although intense risk taking is avoided. In contrast, introducing deposit insurance increases risk taking if banks are competing for deposits. As a result, the deposit rates become extremely high, thus forcing banks to take excessive risks.

Wetmore (2004) examined the correlation between loan-to-deposit and liquidity risk. From his findings, it is found that loan-to-deposit ratio has increased which in turn influenced the change in asset to liability ratio. A positive relation between these two variables has revealed in his study. Wang and Sheng-Yung (2004) examined 
profit diversification among the major banks. Their results suggested that the foreign exchange risk seems the most vulnerable one among the others. In a study of top 20 Japanese banks, Khambata and Bagdi (2003) revealed that the financial derivatives (for example, off-balance-sheet) have been extremely used by the major banks. These banks are using this as profit diversification. Comparing their results of Asian banks with major banks in USA and Europe, Asian banks are lagging behind in practicing profit diversification. Al-Tamimi (2002) investigated commercial banks in UAE. It reveals that the credit risk was a major concern. Credit risk was examined by Salas and Saurina (2002) among the Spanish banks. The study covered 1985-1997 and compared the determinants of problem loans. Various risk management practices in financial organizations became the need of the time just after the financial distress faced by the whole world in last decade. In particular, United States required long time to restore their economy with serious regulatory changes. Many post crisis analysts found dissimilarities in terms of risk identification and management in different banks and financial organization before and during the crisis which was a self-destructive thought that brought such loss to the world economy. Risk management defines the need of identification of core risks, method to develop consistent and accurate risk measurement, give the importance of risk reduction, avoidance and transfer through proper risk return calculation and best monitoring procedures of risk position for the organization. For banks, meeting the regulation not necessarily can avoid bankruptcy or financial harassment. Bank personnel require reliable risk identification, measurement and management culture to follow and monitor best risk-reward ratio.

The term risk is not uncommon in Islamic theory. To understand this concept from Islamic perspective one must look at two dimensions- taking risk without any information and permission of contract without acceptance of Islamic law. Regarding uncertainty, the facts should come under contractual agreement of suspected outcome. For example, the supplier's contractual obligation, where suppliers supposed to deliver a product but not in the position of the product means invalid the contract. Risk sharing is the prime concern of Islamic financial system which deals with not only risk sharing but also economic development through value creation. For example, gambling is also prohibited in Islam though it involves with risk. The reason behind such rule is gambling is a zero sum game and does not contribute in development of economy.

\section{Objectives}

This study compares risk management practices in Islamic and Conventional banks operating in Bangladesh. The study also covers the following areas;

- Awareness of bank personnel concerning various types of risk management techniques.

- Attitudes of bankers towards risk management practices.

- Level of risk management practices.

- Methods of risk identification and mitigation.

- Problems of risk management practices and their removal.

\section{Methodology}

The present research is a qualitative one and has been designed in the following ways:

\subsection{Sample Selection}

There are fifty three commercial banks currently operating in Bangladesh out of which four banks are state-owned, thirty nine are private commercial banks and rest banks are foreign. A total number of fourteen local private commercial banks are selected for the study purpose which covers $26.42 \%$ of the total banks. All the state-owned and foreign commercial banks have been excluded from the study and the reason behind such selection is the nonexistence of the state-owned and foreign Islamic banks in the country. Moreover, public verses private banks seems to be incomparable due to the management policies and government treatment. Among the fourteen sample banks, the number of Islamic and conventional banks is even. Banks are selected based on their length of the operation, value of the firm and number of branches. The total observation of this study is 140 - ten respondents from each bank.

The sample Islamic Banks are as follows (Year in the parentheses is the establishment year of the banks):

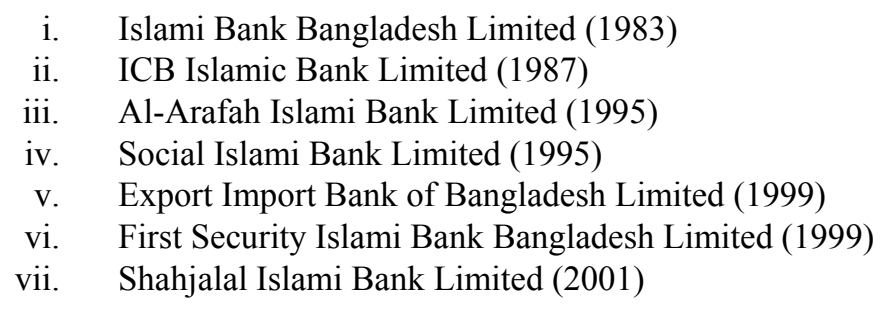


A similar sample size is selected among the Conventional Banks. The banks are:

i. $\quad$ The City Bank Limited(1983)

ii. $\quad$ Eastern Bank Limited (1992)

iii. Dhaka Bank Limited (1995)

iv. Mercantile Bank Limited (1999)

v. Mutual Trust Bank Limited (1999)

vi. Standard Bank Limited(1999)

vii. Jamuna Bank Limited (2001)

\subsection{Data Collection and Questionnaire}

One respondent (In-charge of risk management) has been chosen for collecting the requisite data and information from each of the selected banks. Primary data were collected using a structured questionnaire. The questionnaire was mainly based on three major aspects of risk management practices: risk identification; measurement and mitigation. The first part of the questionnaire included 105 closed-ended questions. In the second part, four open-ended questions were asked.

\subsection{Reliability of the Measures}

The questionnaire focused on three major aspects of risk. It consists of total 119 questions. Using Cronbach's alpha the reliability of data was measured. It explains the estimate of variation used in the variables that are responsible for the error (Selltiz et al., 1976). The rule of thumb is that if the coefficient value lies greater or equal than 0.7 , the variability seems reliable contract (Nunnally, 1978). The overall Cronbach's alpha reveals a value of 0.769. Individually, the Cronbach's alpha for risk identification (RI); risk measurement (RM) and risk management practices (RMP); is (0.679), (0.789) and (0.738) respectively. Hence, a reliable measure of reliability is achieved from all three aspects of this study.

\section{Analysis of the Findings}

The major findings of the questionnaire survey are sub-sectioned into the following headings;

\subsection{Awareness of the Banks' Personnel Regarding Various Types of Risks}

The analysis of the table 1(a) (appendix) reveals among the Islamic and conventional banks, there is a significant difference as regards the level of risk awareness. Considering the awareness of credit/ investment risk and performance of the operational risk, there is no difference. But as regards the other types of risks there is variation between Islamic banks and conventional banks. The highest variation has been observed in case of Shariah non-compliance risk and Interest rate risk followed by price risk. For other risks, the variation of awareness has been observed at $14.3 \%$.

The analysis of table 1(b) (appendix) reveals that there are also variations as regards the level of awareness of the various risks. In case of Islamic banks, $100 \%$ respondents have been highly aware as regards credit/ investment risk, $71.4 \%$ respondents have been highly aware of liquidity risk, foreign exchange/ currency risk and performance/ operational risk. Only $42.9 \%$ respondents have been highly aware environmental risk, rate of return risk and Shariah non-compliance risk. Only $14.3 \%$ respondents have been highly aware of interest risk and price risk. But, in case of conventional banks, $100 \%$ respondents have been highly aware of all types of risk shown in the table excepting Shariah non-compliance risk about which no respondents is highly aware.

\subsection{Cautiousness about the Various Types of Risk}

The concernedness of the various types of risks also varies among the banks as shown in table 2 (appendix). In case of Islamic banks, $100 \%$ respondents have been highly concerned as regards credit/ investment risk; $71.4 \%$ respondents have been highly concerned as regards liquidity risk, environmental risk and rate of return risk each. Only $14.3 \%$ respondents are highly concerned about foreign exchange risk. But in case of conventional banks $100 \%$ respondents have been highly concerned as regards credit risk and Interest risk each. $71.4 \%$ respondents and $57.1 \%$ respondents have been highly concerned regarding liquidity risk and rate of return risk respectively. Only $28.6 \%$ respondents have been highly concerned about foreign exchange/ currency risk, performance risk, environmental risk and price risk each. Therefore, there is a variation as to the awareness and cautiousness of the various risks by the Islamic banks and conventional banks.

\subsection{Risk Identification Techniques and Its Measurement Level}

As regards the awareness of risk identification techniques, table 3(a) (appendix) reveals that all the respondents of both the banks have been aware of risk identification techniques namely inspection by the bank managers and financial audit. As regards the techniques of SWOT analysis, $85.7 \%$ respondents of the Islamic banks have been 
aware. In case of conventional banks, $100 \%$ respondents have been aware of process analysis, SWOT analysis, scenario analysis, benchmarking, and inspection by outsiders. Thus, it can be said that Islamic banks have been aware of only traditional risk identification techniques but the conventional banks have been aware of both traditional and advanced techniques namely process analysis, benchmarking, scenario analysis and internal communication.

There appears to be variation as to the level of risk identification techniques between Islamic and conventional banks. Table 3(b) (appendix) reveals that 100\% respondents of both the banks have been highly aware of inspection by the bank risk managers, financial statement analysis only and physical inspection. Then, in case of Islamic banks $71.4 \%$ respondents have also been highly aware as to SWOT analysis. Whereas, only $28.6 \%$ respondents of conventional banks have been fully aware of these techniques. In case of both Islamic banks and conventional banks, only $28.6 \%$ respondents have been highly aware of the techniques benchmarking and internal communication. Therefore, there is a gap in the practices of risk identification.

\subsection{Use of Various Risk Management Techniques}

Table 4(a) (appendix) presents the picture of use of risk management techniques. The table depicts that $100 \%$ respondents of both the banks have used credit ratings and interest based rating systems. In case of Islamic banks $85.7 \%$ respondents have used duration analysis, credit scoring and credit scoring committee techniques each. Again, $71.4 \%$ respondents have used scenario analysis and stress testing techniques. In case of conventional banks, $100 \%$ respondents have used scenario analysis, maturity matching, simulation techniques, Interest based rating, credit scoring and credit committee techniques each. Again, $71.4 \%$ respondents have followed GAP analysis and stress testing techniques each. Therefore, it can be said that both the Islamic banks and conventional banks used traditional techniques and as well as advanced techniques while measuring risk in their banks.

As regards the frequency of use of risk management techniques by the selected sample table 5(b) (appendix) has been presented. The said table depicts that in case of Islamic banks $85 \%$ respondents have mostly used the techniques credit scoring and credit committees. $71.4 \%$ respondents have mostly used the techniques credit rations, duration analysis, maturity matching and stress testing. But, in case of conventional banks, $100 \%$ respondents mostly used credit scoring. $71.4 \%$ respondents and $57.1 \%$ respondents mostly used credit committees and interest based rating system respectively. Only $28.6 \%$ respondents have used scenario analysis, tress testing, and credit scoring. From the above analysis it can be said that vast majority of the respondents of Islamic banks have mostly used the majority risk management techniques. Alternatively, vast majority of the respondents have frequently used the updated risk management techniques in the conventional banks. Therefore, there is a variation in the understanding the risk management practices among the banks.

\subsection{Risk Mitigation Approaches}

Table 5(a) (appendix) presents the picture of use of risk mitigation approaches in the sample banks. The table depicts that In case of Islamic banks $100 \%$ respondents have agreed about risk reduction. $85.7 \%$ respondents have agreed to avoid risk and $42.9 \%$ have agreed to use the approach of risk mitigation namely; risk transferring and risk sharing. Only $28.6 \%$ respondents have agreed for risk retention technique. In case of conventional banks all the respondents have agreed for risk retention, transferring, sharing and risk reduction techniques. Only $28.6 \%$ respondents have agreed for risk avoidance techniques for risk mitigation. Therefore, it can be said from the above findings that Islamic banks have been using the approaches as mentioned in table 5(a) to lesser extent to mitigate risk of their banks than that of conventional banks.

As regards the level of use of risk mitigation approaches by the selected sample table 5(b) (Appendix) has been presented. In case of Islamic banks $71.86 \%$ respondents have highly agreed for the risk reduction approach for risk mitigation in their banks followed by risk avoidance by $85.7 \%$, risk transferring and risk sharing by $42.9 \%$ each and only $28.6 \%$ respondents have highly agreed for risk retention approach. The said table depicts that in case of conventional banks, only $28.6 \%$ respondents have highly agreed for using risk avoidance approach. Again, only $14.3 \%$ respondents have only agreed for the risk avoidance, risk retention and risk reduction approaches. From the above analysis it can be said that simple majority of the respondents of Islamic banks have highly agreed for various risk mitigation approaches than that of conventional banks. In case of conventional banks vast majority of the respondents have only agreed to use few of the approaches for risk mitigation in their banks.

\subsection{Awareness of Risk Mitigation Techniques \& Measurement}

Table 6(a) (appendix) depicts significance difference regarding the specific risk mitigation techniques. Results from the questionnaire suggest that Islamic banks are less aware about following techniques compared to 
conventional banks, namely; classified loans, and over the counter derivatives. In addition, all the respondents have found aware of collateral agreement and guarantees. However, Islamic banks have found higher awareness only for the third party enhancement compared to conventional banks by around $14.3 \%$.

Even though table 6(a) (appendix) suggests that Islamic banks are less aware in terms of aware of the techniques for risk mitigation, table 6(b) (appendix 01) depicts different results, the uses of different risk mitigation techniques have been found higher. As regards Islamic banks, guarantees has found highly used by all the banks. collateral agreement, loan loss reserves, third party enhancement, parallel contract and on balance sheet netting and Over the counter derivatives have been using by the Islamic Banks by $85.7 \%, 71.4 \%, 57.1 \%, 28.6 \% 28.6 \%$ and $14.3 \%$ respectively. As opposed regarding the conventional banks, all the respondents have said that collateral has highly been used for risk mitigation. However, $71.4 \%$ agreed that third party enhancement and loan loss reserves have only used by the banks. In addition, all the respondents also opined that on balance sheet netting, guarantees and parallel contracts have neutral as to the use for the same purposes. The above findings suggest that conventional banks fully concentrate on risk mitigation using collateral, third party enhancement and Loan loss reserve which has also marked as high usability by the Islamic banks. Therefore, risk management practices has positive association with risk identification and mitigation.

\subsection{Attitude of Management towards Risk Management Practices}

Refer to the table 7 (appendix), management attitude towards risk management seems favourable both banks. As regards particular risk, a slight difference has been observed. All the respondents of Islamic banks have shown highly positive attitude towards credit risk and liquidity risk; $85.7 \%$ respondents showed highly positive attitudes towards performance risk. It is found that the foreign exchange risk as well as the interest rate risk have been found highly positive with $42.4 \%$ and $14.3 \%$ respectively. As regards conventional banks, $100 \%$ respondents showed highly positive attitude towards Credit risk followed by liquidity risk by $57 \%$.

\subsection{Problems in Risk Management Practices}

At this stage, our respondents were asked to mention the major problems and the suggestions for the removal of the same. Table 8 depicts the picture in this regards. The table reveals that Lack of qualified and experienced personnel ranks first as it is mentioned by $50 \%$ of the total respondents. This has similarity with the findings of Masum, Azad and Beh (2015). Followed by poor loan recovery problem which is mentioned by $30.77 \%$ respondent; followed by lack of market information as it is mentioned by $23.8 \%$ and the remaining problems namely- capital inadequacy, improper credit identification and rating, short term guideline from Bangladesh Bank, weak liquidity management and poor loan monitoring have ranked 6th each as mentioned by $15.38 \%$ respondents.

The respondents have mentioned the following suggestions for the removal of above mentioned problems.

i. Adequate market information needs to be available by setting central management information system (MIS).

ii. Capital adequacy of the banks should be met as far as possible

iii. Loan recovery should be strengthening by moral persuasion of the borrowers.

iv. Credit identification and rating system should be included

v. Long term guideline should be provided by the Central Bank.

vi. Improving liquidity management of the banks by providing more liquid assets.

vii. Loan monitoring system should be improved as far as possible.

\section{Conclusion and Policy Implication}

From the results, it can be concluded that risk management is the most important strategic management activity in a bank. This is because of the fact that banking business itself is a business of risk. Therefore, Managers must give due emphasis on the management of various types of risks. The study reveals that there are variations in understanding of risk (awareness of risk), using risk management techniques as well as risk mitigation techniques. The study also reveals that conventional banks use advanced methods of risk identification techniques, risk management techniques as well as risk mitigation techniques to a great extent along with traditional techniques. So, these banks give due importance to the advanced techniques of risk management as a whole. But, the Islamic banks give more emphasis on traditional methods of risk identification, risk management and risk mitigation techniques because of shortage of qualified and experienced bank officials.

The following policy implications may be followed for efficient risk management practices;

i. Bangladesh bank guidelines concerning the risk management techniques must be followed by the banks in to-to without failure. 
ii. Providing market information as to the various types of the risk is a must for the banks.

iii. Adequate information must be provided for setting up central MIS system by the banks.

iv. High loan recovery rates must be ensured in order to make the banks more sustainable since it is one of the criteria of financial sustainability of the banks. In these respects, sectioning loans and advances after proper appraisal of the loan application by the bank authority is a must. In this respect, loan monitoring systems are also required to be included.

These policy implications cannot be implemented by the respective banks' authority. The role of Bangladesh Bank, as the guardian of commercial banks, is also essential.

\section{References}

Al-Tamimi, H. (2002). Risk Management Practices: An Empirical Analysis of the UAE Commercial Banks, Finance India, 16(3), 1045-1057.

Anderson, R. A., Sweeney, D. J., \& Williams, T. A. (1990). Statistics for Business and Economics. West Publishing Company, St. Paul, MN.

Basel Committee on Banking Supervision. (1999). Principles for the Management of Credit Risk, Consultative Paper Issued by the Basel Committee on Banking Supervision, Issued for Comment by 30 November, pp. 3-19.

Carey, A. (2001). Effective Risk Management in Financial Institutions: the Turnbull Approach. Balance Sheet, 9(3), 24-37. http://dx.doi.org/10.1108/09657960110696014

Devellis, R. F. (1991). Scale Development: Theory and Application. Applied Research Methods Service, 26. Sage Publications, Newbury Park, CA.

Emirates Banks Associations. (2004). Scale Development: Theory and Application, Applied Research Methods Service. Emirates Banks Associations, Abu Dhabi.

Hahm, J. H. (2004). Interest Rate and Exchange Rate Exposures of Banking Institutions in Pre-crisis Korea. Applied Economics, 36(13), 1409-1419. http://dx.doi.org/10.1080/0003684042000206979

Islamic Financial Service Board. (2005). IFSB-1: Guiding Principles of Risk Management for Institutions (other than Insurance Institutions) offering only Islamic Financial Services (IIFS). Kuala Lumpur, Malaysia: Islamic Financial Service Board.

Islamic Financial Service Board. (2008). Technical Note on Issues in Strengthening Liquidity Management of Institutions Offering Islamic Financial Services: The Development of Islamic Money Market. Kuala Lumpur, Malaysia: Islamic Financial Service Board.

Khambata, D., \& Bagdi, R. R. (2003). Off-balance-sheet Credit Risk of the top 20 Japanese Banks, Journal of International Banking Regulation, 5(1), 57-71. http://dx.doi.org/10.1057/palgrave.jbr.2340157

Khan, T., \& Ahmed, H. (2001). Risk Management: An Analysis of Issues in Islamic Financial Industry, Occasional Paper No. 5. Islamic Research \& Training Institute (IRTI), Islamic Development Bank, Jeddah.

Linbo F. L. (2004). Efficiency versus Risk in Large Domestic US. Managerial Finance, 30(9), 1-19. http://dx.doi.org/10.1108/03074350410769245

Masum, A. K. M., Azad, M. A. K., \& Beh, L. S. (2015). The Role of Human Resource Management Practices in Bank Performance. Total Quality Management \& Business Excellence, 35(3), 1-16. http://dx.doi.org/10.1080/14783363.2014.1002762

Niinima"ki, J. P. (2004). The Effects of Competition on Banks' Risk Taking. Journal of Economics, 81(3), 199-222. http://dx.doi.org/10.1007/s00712-003-0027-9

Nunnally, C. J. (1978). Psychometric Theory. McGraw-Hill, New York, NY.

Oldfield, G. S., \& Santomero, A. M. (1997). Risk Management in Financial Institutions. Sloan Management Review, 39(1), 33-46. Retrieved from http://www.federalreserve.gov/newsevents/speech/bernanke200805 15a.htm

Salas, V., \& Saurina, J. (2002). Credit Risk in two Institutional Regimes: Spanish Commercial and Savings Banks. The Journal of Financial Services Research, 22(3), 203-216. http://dx.doi.org/10.1023/A:10197 81109676

Selltiz, C., Wrightsman, L. S., \& Cook, W. (1976). Research Methods in Social Relations. Holt, Rinehart and 
Winston, New York, NY.

Wang, A. T., \& Sheng-Yung, Y. (2004). Foreign Exchange Risk, World Diversification and Taiwanese ADRs. Applied Economics Letters, 11(12), 755-768. http://dx.doi.org/10.1080/1350485042000254629

Wetmore, J. L. (2004). Panel Data, Liquidity Risk, and Increasing Loans-to-cor Deposits Ratio of Large Commercial Bank Holding Companies. American Business Review, 22(2), 99-107.

\section{Appendix}

Table 1(a). Awareness of different types of risks

\begin{tabular}{|c|c|c|c|c|c|c|c|c|}
\hline Type of Risk & Islamic Banks (IBs) & $\%$ & Mean & SD & Conventional Banks (CBs) & $\%$ & mean & SD \\
\hline Credit Risk / Investment Risk & 7 & 100 & 1.00 & .000 & 7 & 100 & 1.00 & .000 \\
\hline Liquidity Risk & 6 & 85.7 & 1.14 & .378 & 7 & 100 & 1.00 & .000 \\
\hline Interest Rate Risk & 2 & 28.6 & 1.71 & .488 & 7 & 100 & 1.00 & .000 \\
\hline Foreign Exchange/ Currency Risk & 6 & 85.7 & 1.14 & .378 & 7 & 100 & 1.00 & .000 \\
\hline Performance/ Operational Risk & 7 & 100 & 1.00 & .000 & 7 & 100 & 1.00 & .000 \\
\hline Environmental Risk & 5 & 71.4 & & & 7 & 100 & 1.00 & .000 \\
\hline Rate of Return Risk & 6 & 85.7 & 1.14 & .378 & 7 & 100 & 1.00 & .000 \\
\hline Shari'a non-compliance Risk & 6 & 85.7 & 1.14 & .378 & 2 & 28.6 & 1.71 & .488 \\
\hline Price risk & 2 & 28.6 & 1.71 & .488 & & 100 & 1.00 & .000 \\
\hline
\end{tabular}

Table 1(b). Level of awareness as regards to various risks

\begin{tabular}{ccccccccccc}
\hline \multirow{2}{*}{ Type of Risk } & \multicolumn{2}{c}{ Highly Aware } & \multicolumn{2}{c}{ Only Aware } & \multicolumn{2}{c}{ Not at all aware } & \multicolumn{2}{c}{ Mean } & \multicolumn{3}{c}{ SD } \\
\cline { 2 - 11 } & IBs & CBs & IBs & CBs & IBs & CBs & IBs & CBs & IBs & CBs \\
\hline Credit Risk/ Investment Risk & 100 & 100 & & & & & 5 & 5 & .00 & .00 \\
Liquidity Risk & 71.45 & 100 & 28.6 & & & & 4.71 & 5 & .488 & .00 \\
Interest Rate Risk & 14.3 & 100 & & & 71.4 & 1.67 & 5 & 1.633 & .00 \\
Foreign Exchange/ Currency Risk & 71.4 & 100 & 14.3 & & 14.3 & 4.29 & 5 & 1.496 & .00 \\
Performance/ Operational Risk & 71.4 & 100 & 14.3 & & 14.3 & 4.29 & 5 & 1.496 & .00 \\
Environmental Risk & 42.9 & 100 & 42.9 & & 14.3 & 4.00 & 5 & 1.212 & .00 \\
Rate of Return Risk & 42.9 & 100 & 42.9 & & 14.3 & 4.00 & 5 & 1.212 & .00 \\
Shari'a non-compliance Risk & 42.9 & & 57.1 & & 28.6 & 1.00 & 1.86 & .535 & 1.46 \\
Price Risk & 14.3 & 100 & & & 71.4 & & 1.67 & 5 & 1.633 & .00 \\
\hline
\end{tabular}

Table 2. Concernedness for various types of risks

\begin{tabular}{|c|c|c|c|c|c|c|c|c|c|c|c|c|}
\hline \multirow[t]{2}{*}{ Type of Risk } & \multicolumn{2}{|c|}{$\begin{array}{c}\text { Highly } \\
\text { Concerned }\end{array}$} & \multicolumn{2}{|c|}{$\begin{array}{c}\text { Only } \\
\text { Concerned }\end{array}$} & \multicolumn{2}{|c|}{ Neutral } & \multicolumn{2}{|c|}{$\begin{array}{l}\text { Not at all } \\
\text { Concerned }\end{array}$} & \multicolumn{2}{|c|}{ Mean } & \multicolumn{2}{|c|}{ SD } \\
\hline & IBs & $\mathrm{CBs}$ & IBs & $\mathrm{CBs}$ & IBs & CBs & IBs & $\mathrm{CBs}$ & IBs & CBs & IBs & CBs \\
\hline Credit risk/Investment risk & 100 & 100 & & & & & & & 5 & 5 & 1.13 & .00 \\
\hline Liquidity risk & 71.4 & 71.4 & 28.6 & 28.6 & & & & & 4.71 & 4.71 & 1.46 & .48 \\
\hline Interest rate risk & & 100 & 14.3 & & & & 71.4 & & 1.57 & 5 & .78 & .00 \\
\hline Foreign exchange/ Currency risk & 14.3 & 28.6 & 28.6 & 42.9 & 57.1 & 28.6 & & & 4.14 & 4 & 1.49 & .81 \\
\hline Performance/ Operational risk & & 28.6 & 71.4 & & & 71.4 & 28.6 & & 3.57 & 3.57 & .787 & .97 \\
\hline Environmental risk & 71.4 & 28.6 & 14.3 & 71.4 & & & 14.3 & & 3.14 & 4.29 & 1.46 & .48 \\
\hline Rate of return risk & 71.4 & 57.1 & 14.3 & 28.6 & 14.3 & 14.3 & & & 4.29 & 4.43 & 1.496 & .78 \\
\hline Shari'a non-compliance risk & & 28.6 & & 71.4 & 14.3 & & 57.1 & & 4.57 & 2.14 & .787 & 1.95 \\
\hline Price risk & & 28.6 & & 71.4 & & & & & 1.40 & 4.29 & .894 & .48 \\
\hline
\end{tabular}

Table 3(a). Awareness of the risk identification techniques

\begin{tabular}{|c|c|c|c|c|c|c|c|c|}
\hline & Islamic & $\%$ & mean & $\mathrm{SD}$ & Conventional & $\%$ & Mean & $\mathrm{SD}$ \\
\hline Inspection by the bank risk manager & 7 & 100 & 1.00 & .00 & 7 & 100 & 1.00 & .000 \\
\hline Audits or physical inspection & 7 & 100 & 1.00 & .00 & 7 & 100 & 1.00 & .000 \\
\hline Financial statement analysis & 7 & 100 & 1.00 & .00 & 7 & 100 & 1.00 & .000 \\
\hline Risk survey & 1 & 14.3 & 1.86 & .378 & 2 & 28.6 & 1.71 & .488 \\
\hline Process analysis & 1 & 14.3 & 1.14 & .378 & 7 & 100 & 1.00 & .000 \\
\hline
\end{tabular}




\begin{tabular}{ccccccccc}
\hline SWOT analysis & 6 & 85.7 & 1.57 & .535 & 7 & 100 & 1.00 & .000 \\
Inspection by outside expert & 3 & 42.9 & 1.86 & .378 & 7 & 100 & 1.00 & .000 \\
Benchmarking & & 14.3 & 1.29 & .488 & 2 & 28.6 & 1.71 & .488 \\
Scenario analysis & 5 & 71.4 & .57 & .535 & 7 & 100 & 1.00 & .000 \\
Internal communication & 3 & 42.9 & .57 & .535 & 7 & 100 & 1.00 & .000 \\
\hline
\end{tabular}

Table 3(b). Level of awareness of risk identification techniques

\begin{tabular}{|c|c|c|c|c|c|c|c|c|c|c|c|c|}
\hline \multirow[t]{2}{*}{ Type of Risk } & \multicolumn{2}{|c|}{ Highly Aware } & \multicolumn{2}{|c|}{ Only Aware } & \multicolumn{2}{|c|}{ Neutral } & \multicolumn{2}{|c|}{$\begin{array}{c}\text { Not at all } \\
\text { aware }\end{array}$} & \multicolumn{2}{|c|}{ Mean } & \multicolumn{2}{|c|}{ SD } \\
\hline & IBs & $\mathrm{CBs}$ & IBs & $\mathrm{CBs}$ & IBs & $\mathrm{CBs}$ & IBs & CBs & IBs & $\mathrm{CBs}$ & IBs & $\mathrm{CBs}$ \\
\hline Inspection by the bank risk manager & 100 & 100 & & & & & & & 5 & 5 & .000 & .000 \\
\hline Audits or physical inspection & 100 & 100 & & & & & & & 5 & 5 & .000 & .000 \\
\hline Financial statement analysis & 100 & 100 & & & & & & & 5 & 5 & .000 & .000 \\
\hline Risk survey & 14.3 & 28.6 & & & & 14.3 & 71.4 & 57.11 & 2.00 & 2.43 & 1.63 & 1.402 \\
\hline Process analysis & & 28.6 & 14.3 & 14.3 & & & 71.4 & 57.1 & 2.08 & 2.57 & 1.706 & 1.488 \\
\hline SWOT analysis & 71.4 & 28.6 & 14.3 & 71.4 & & & 14.3 & & 4.29 & 4.29 & 1.069 & .488 \\
\hline Inspection by outside expert & 28.6 & 28.6 & 14.3 & 57.1 & & & 57.1 & & 3.38 & 4.33 & 1.710 & .516 \\
\hline Benchmarking & 14.3 & 28.6 & & & & & 71.4 & 28.6 & 2.20 & 3.00 & 1.932 & 2.309 \\
\hline Scenario analysis & 28.6 & 28.6 & 42.9 & & 14.3 & 28.6 & 28.6 & 42.9 & 3.07 & 2.71 & 1.730 & 1.799 \\
\hline Internal communication & 14.3 & & 14.3 & & 14.3 & 42.9 & 42.9 & 28.6 & 2.36 & 2.20 & 1.433 & 1.043 \\
\hline
\end{tabular}

Table 4(a). Use of risk management techniques

\begin{tabular}{cccccccccc}
\hline & Islamic & $\%$ & Mean & SD & Conventional & $\%$ & Mean & SD \\
\hline Credit Ratings & 7 & 100 & 1.00 & .000 & 7 & 100 & 1.00 & .000 \\
Gap Analysis & 5 & 71.4 & 1.29 & .488 & 5 & 71.4 & 1.29 & .488 \\
Scenario Analysis & 5 & 71.4 & 1.29 & .4888 & 7 & 100 & 1.00 & .000 \\
Duration Analysis & 6 & 85.7 & 1.14 & .378 & 2 & 28.6 & 1.71 & .488 \\
Maturity Matching & 3 & 42.9 & 1.71 & .488 & 7 & 100 & 1.00 & .488 \\
Earning at risk & 2 & 28.6 & 1.29 & .488 & 2 & 28.6 & & .000 \\
Value at risk & 5 & 71.4 & 2.00 & .000 & 7 & 100 & 1.00 & .000 \\
Simulation techniques & 4 & & 1.29 & .488 & 7 & 100 & 2.00 & .000 \\
Stress testing & 5 & 71.4 & 2.00 & .000 & 5 & 71 & 1.29 & .488 \\
Risk adjusted return on capital & 1 & 14.38 & 1.29 & .488 & 7 & 100 & 1.00 & .000 \\
Internal Based rating system & 7 & 100 & 1.86 & .378 & 7 & 100 & 1.29 & .488 \\
Credit Scoring & 6 & 85.7 & 2.00 & .000 & 7 & 100 & 1.00 & .000 \\
Credit committees & 6 & 85.7 & 1.14 & 1.14 & 7 & 100 & 1.00 & .000 \\
\hline
\end{tabular}

Table 4(b). Frequency of using risk management techniques

\begin{tabular}{|c|c|c|c|c|c|c|c|c|c|c|c|c|}
\hline \multirow[t]{2}{*}{ Type of Risk } & \multicolumn{2}{|c|}{ Mostly Used } & \multicolumn{2}{|c|}{$\begin{array}{c}\text { Frequently } \\
\text { Used }\end{array}$} & \multicolumn{2}{|c|}{ Rarely Used } & \multicolumn{2}{|c|}{ Not at all used } & \multicolumn{2}{|c|}{ Mean } & \multicolumn{2}{|c|}{ SD } \\
\hline & IBs & $\mathrm{CBs}$ & IBs & $\mathrm{CBs}$ & IBs & $\mathrm{CBs}$ & IBs & $\mathrm{CBs}$ & IBs & $\mathrm{CBs}$ & IBs & $\mathrm{CBs}$ \\
\hline Credit Ratings & 71.4 & 25.5 & 28.6 & 71.4 & & & & & 4.71 & 4.29 & .488 & .488 \\
\hline Gap Analysis & 14.3 & 14.3 & 57.1 & & & & 28.6 & 28.6 & 3.29 & 2.71 & 1.604 & 1.380 \\
\hline Scenario Analysis & 42.9 & 28.6 & 42.9 & & & 42.9 & 14.3 & & 4.00 & 3.14 & 1.414 & 1.385 \\
\hline Duration Analysis & 71.1 & 28.6 & & & & 28.6 & 28.6 & 42.4 & 3.86 & 2.43 & 1.452 & 1.813 \\
\hline Maturity Matching & 71.3 & 28.6 & 14.3 & & & 42.6 & 14.3 & 28.6 & 4.29 & 2.57 & 1.496 & 1.718 \\
\hline Earning at risk & 14.3 & 28.6 & 14.3 & & & & 71.4 & 71.4 & 2.00 & 2.14 & 1.732 & 1.452 \\
\hline Value at risk & & 28.6 & 71.4 & & & & 28.6 & 14.3 & 3.14 & 3.67 & 1.464 & 2.306 \\
\hline Simulation techniques & & 28.6 & & & & & 100 & 71.4 & 1.00 & 1.57 & .00 & .976 \\
\hline Stress testing & 71.4 & & & & & & 28.6 & 28.6 & 3.86 & 2.43 & 1,452 & .976 \\
\hline Risk adjusted return & 14.3 & 28.6 & & & & & 85.7 & & 4.29 & 3.57 & 1.496 & .976 \\
\hline Internal Based rating & & 57.1 & & & & & 100 & & 2.00 & 4.14 & 1.732 & 1.069 \\
\hline Credit Scoring & 85.7 & 100 & & & & & 14.3 & & 3.14 & 5.00 & 1.464 & .000 \\
\hline Credit committees & 85.7 & 71.4 & & 28.6 & & & 14.3 & & 4.43 & 4.71 & 1.512 & .488 \\
\hline
\end{tabular}


Table 5(a). Risk mitigation approaches

\begin{tabular}{|c|c|c|c|c|c|c|c|c|}
\hline Approach & Islamic & $\%$ & Mean & SD & Conventional & $\%$ & mean & SD \\
\hline Risk may be avoided & 6 & 85.7 & 1.14 & .378 & 2 & 28.6 & 1.71 & .488 \\
\hline Risk may be retained & 2 & 28.6 & 1.71 & .488 & 7 & 100 & 2.00 & .00 \\
\hline Risk may be transferred & 3 & 42.9 & 1.57 & .535 & 7 & 100 & 2.00 & .00 \\
\hline Risk may be shared & 3 & 42.9 & 1.57 & .535 & 7 & 100 & 2.00 & .00 \\
\hline Risk may be reduced & 7 & 100 & 1.00 & .000 & 7 & 100 & 1.00 & .00 \\
\hline
\end{tabular}

Table 5(b). Level of acceptance of various risk mitigation approaches

\begin{tabular}{|c|c|c|c|c|c|c|c|c|c|c|c|c|}
\hline \multirow[t]{2}{*}{ Type of Risk } & \multicolumn{2}{|c|}{ Highly agreed } & \multicolumn{2}{|c|}{ Only agreed } & \multicolumn{2}{|c|}{ Disagreed } & \multicolumn{2}{|c|}{$\begin{array}{c}\text { Highly } \\
\text { Disagreed }\end{array}$} & \multicolumn{2}{|c|}{ Mean } & \multicolumn{2}{|c|}{ SD } \\
\hline & IBs & $\mathrm{CBs}$ & IBs & $\mathrm{CBs}$ & IBs & $\mathrm{CBs}$ & IBs & $\mathrm{CBs}$ & IBs & $\mathrm{CBs}$ & IBs & $\mathrm{CBs}$ \\
\hline Risk may be avoided & 14.3 & 28.6 & 14.3 & & & & 71.4 & 71.4 & 3.71 & 2.14 & 1.234 & 1.452 \\
\hline Risk may be retained & 14.3 & & 14.3 & & & 28.6 & 71.4 & 71.4 & 2.00 & 1.29 & 1.732 & .488 \\
\hline Risk may be transferred & 42.4 & & & & & 28.6 & 57.1 & 71.4 & 2.71 & 1.29 & 2.138 & .488 \\
\hline Risk may be shared & 28.6 & & & & & & 71.4 & 100 & 2.14 & 1.00 & 1.432 & .000 \\
\hline Risk may be reduced & 71.6 & & 14.3 & & & & 14.3 & 100 & 4.29 & 5.00 & 1.496 & .000 \\
\hline
\end{tabular}

Table 6(a). Awareness of respondents for risk mitigation techniques

\begin{tabular}{|c|c|c|c|c|c|c|c|c|}
\hline & Islamic & $\%$ & Mean & SD & Conventional & $\%$ & Mean & SD \\
\hline Collateral Arrangement & 7 & 100 & 1.00 & .000 & 7 & 100 & 1.00 & .000 \\
\hline Third party enhancement & 6 & 85.7 & 1.14 & .378 & 5 & 71.4 & 1.29 & .428 \\
\hline Loan loss reserves & 5 & 71.4 & 1.29 & .488 & 7 & 100 & & \\
\hline On balance sheet netting & 4 & 42.9 & 1.57 & .535 & 5 & 71.4 & 1.00 & \\
\hline Guarantees & 7 & 100 & 1.00 & .000 & 7 & 100 & 1.29 & .000 \\
\hline Parallel contracts & 2 & 28.6 & 1.71 & .488 & 7 & 100 & 1.00 & .488 \\
\hline Over the Counter derivatives & 6 & 85.7 & 2.00 & .000 & 7 & 100 & 2.00 & .000 \\
\hline
\end{tabular}

Table 6(b). Level of using specific risk mitigation techniques

\begin{tabular}{|c|c|c|c|c|c|c|c|c|c|c|c|c|}
\hline \multirow{2}{*}{ Type of Risk } & \multicolumn{2}{|c|}{ Highly used } & \multicolumn{2}{|c|}{ Only used } & \multicolumn{2}{|c|}{ Neutral } & \multicolumn{2}{|c|}{ Not at all used } & \multicolumn{2}{|c|}{ Mean } & \multicolumn{2}{|c|}{ SD } \\
\hline & IBs & $\mathrm{CBs}$ & IBs & $\mathrm{CBs}$ & IBs & $\mathrm{CBs}$ & IBs & $\mathrm{CBs}$ & IBs & $\mathrm{CBs}$ & IBs & $\mathrm{CBs}$ \\
\hline Collateral Arrangement & 85.7 & 100 & 14.3 & & & & & & 4.86 & 5.00 & .378 & .00 \\
\hline Third party enhancement & 57.1 & 28.6 & 28.6 & 71.4 & & & 14.3 & & 4.14 & 4.29 & 1.464 & .488 \\
\hline Loan loss reserves & 71.4 & 28.6 & & 71.4 & & & 28.6 & & 3.86 & 3.29 & 1.452 & .488 \\
\hline On balance sheet netting & 28.6 & & 14.3 & & & 100 & 57.1 & & 2.57 & 3.00 & 1.488 & .000 \\
\hline Guarantees & 100 & & & & & 100 & & & 5.00 & 5.00 & .00 & .000 \\
\hline Parallel contracts & 28.6 & & & & & 100 & 71.4 & & 1.86 & 1.86 & 1.145 & 1.464 \\
\hline Over the Counter derivatives & 14.3 & & & & & 28.6 & 85.7 & 71.4 & 1.86 & 1.86 & & 1.464 \\
\hline
\end{tabular}

Table 7. Attitude of management towards risk management practices

\begin{tabular}{|c|c|c|c|c|c|c|c|c|c|c|c|c|}
\hline \multirow[t]{2}{*}{ Type of Risk } & \multicolumn{2}{|c|}{ Highly Positive } & \multicolumn{2}{|c|}{ Only Positive } & \multicolumn{2}{|c|}{ Neutral } & \multicolumn{2}{|c|}{$\begin{array}{c}\text { Highly } \\
\text { Negative }\end{array}$} & \multicolumn{2}{|c|}{ Mean } & \multicolumn{2}{|c|}{ SD } \\
\hline & IBs & $\mathrm{CBs}$ & IBs & $\mathrm{CBs}$ & IBs & $\mathrm{CBs}$ & IBs & CBs & IBs & $\mathrm{CBs}$ & IBs & $\mathrm{CBs}$ \\
\hline Credit Risk & 100 & 100 & & & & & & & 5.00 & 5.00 & 000 & .000 \\
\hline Liquidity Risk & 100 & 57,1 & & 14.3 & & & & 28.6 & 5.00 & 3.71 & 000 & 1.84 \\
\hline Interest Rate Risk & 14.3 & 28.6 & 14.3 & 28.6 & & 14.3 & 71.4 & 28.6 & 2.00 & 3.29 & 1.732 & 1.764 \\
\hline Foreign Exchange Risk & 42.6 & 28.6 & 57.1 & 42.4 & & 28.6 & & & 4.13 & 4.00 & .535 & .816 \\
\hline Performance Risk & 85.7 & 28.6 & & & 14.3 & 57.1 & & & 4.71 & 3.67 & .756 & 1.033 \\
\hline
\end{tabular}

Table 8. Problems in risk management

\begin{tabular}{ccc}
\hline Specific Problem & Frequency of the respondents & Percentage (\%) \\
\hline Lack of market information & 3 & $23.08 \%$ \\
Capital inadequacy & 2 & $15.38 \%$ \\
\hline
\end{tabular}


Poor loan recovery

Improper Credit identification and rating

Short term guideline from BB

Weak liquidity management

Poor Loan monitoring

Lack of qualified and experienced personnel

$\begin{array}{ll}4 & 30.77 \% \\ 2 & 15.38 \% \\ 2 & 15.38 \% \\ 2 & 15.38 \% \\ 2 & 15.38 \% \\ 7 & 50.00 \%\end{array}$

\section{Copyrights}

Copyright for this article is retained by the author(s), with first publication rights granted to the journal.

This is an open-access article distributed under the terms and conditions of the Creative Commons Attribution license (http://creativecommons.org/licenses/by/3.0/). 